\title{
SISTEM DIAGNOSA PENYAKIT THT PADA BALITA MENGGUNAKAN DEMPSTER SHAFER
}

\author{
Maura Widyaningsih \\ Prodi Teknik Informatika STMIK Palangkaraya \\ Jl. Obos 114 Palangkaraya \\ e-mail: maurawdya@gmail.com
}

\begin{abstract}
ABSTRAK
Bidang komputer mendukung adanya program bantu dalam perkembangan medis yaitu sistem yang berbasis pengetahuan si Pakar, sistem ini merupakan salah satu cabang dari Artifical Intellegence (AI). Sistem pakar merupakan pengetahuan dalam mempelajari tentang estimasi atau kemampuan pengambilan keputusan dari seorang pakar. Problem solving dalam identifikasi suatu penyakit dengan menggunakan program bantu sangat diperlukan suatu metode dan konsep. Teknik perhitungan dalam sistem komputasi begitu pentingnya, mengingat tingkat kebutuhan akan informasi dan penyelesaian kasus secara cepat.

Hasil penelitian adalah aplikasi pakar yang membantu dalam memberikan hasil diagnosa gejala yang dikelola di dalam sistem, dengan inferensi menggunakan forward chaining, dan reasioning dengan Dempster Shafer. Metode Dempster Shafer tidak monoton dalam penyelesaian masalah ketidakpastian, akibat adanya penambahan ataupun pengurangan fakta baru. Perubahan aturan akan terjadi, sehingga memungkinkan sistem dapat melakukan pekerjaan seorang pakar.

Perubahan data dapat dilakukan baik terhadap penyakit, gejala, solusi dan aturan, sehingga memungkinkan sistem dapat melakukan pekerjaan seorang pakar. Hasil perhitungan manual dengan sistem memberikan hasil yang sesuai dengan penerapan metode Dempster Shafer. Pengelolaan aturan di database memudahkan penelusuran gejala didalam sistem.
\end{abstract}

Kata Kunci: Sistem Diagnosa penyakit, THT pada balita, Dempster Shafer.

\begin{abstract}
Computer field supports the existence of auxiliary program in medical development that is expert knowledge-based system, this system is one branch of Artifical Intellegence (AI). Expert systems are knowledge in learning about estimation or decisionmaking ability of an expert. Problem solving in the identification of a disease by using auxiliary program is needed a method and concept. Calculation techniques in computing systems are so important, given the level of need for information and the settlement of cases quickly.

The results of the study are expert applications that assist in providing results of diagnosis of symptoms managed the system, with inference using forward chaining, and reasioning with Dempster Shafer. Dempster Shafer's method is not monotonous in solving uncertainty problems, due to the addition or subtraction of new facts. Rule changes will occur, allowing the system to do the work of an expert.

Data changes will occur both to diseases, symptoms, solutions and rules, allowing the system to do the work of an expert. The results of manual calculations with the system gives results in accordance with the application of Dempster Shafer method. Management of rules in the database facilitates the search for symptoms within the system.
\end{abstract}

Keywords: Diagnosis System for desease, Ear Nose and Throat (ENT) disease in toddle, Dempster Shafer.

\section{PENDAhUluan}

$\mathrm{P}$ enyakit sering disebabkan oleh virus, bakteri dan jamur. Penyakit yang terjadi pada balita sangat banyak dan membutuhkan penanganan untuk penyembuhannya. Dalam penelitian ini penyakit yang diangkat pada balita adalah berkenaan dengan telinga, hidung dan tenggorokan (THT). Dokter di rumah sakit, klinik ataupun Puskesmas sebelum memberikan jawaban hasil diagnosa jenis penyakit, akan dilakukan terlebih dahulu terhadap timbulnya gejala-gejala yang menyerang balita. Penanganan terhadap banyaknya pasien balita membutuhkan waktu untuk penanganan yang panjang, dengan tenaga medis yang terbatas. Melihat permasalahan tersebut teknologi komputer menawarkan kemudahan untuk pemecahan solusi waktu penanganan diagnosa.

Penelitian Expert Systems (ES) telah menjadi salah satu bidang penelitian terpanjang yang pernah ada dan paling berhasil dalam bidang Artifical Intelegence (AI) . Banyak studi kasus aplikasi ES telah dipublikasikan yang mencakup berbagai area fungsional dan domain masalah. ES telah dikembangkan dengan berbagai alat, konsep, dan penerapan yang mengalami evolusi hingga dekade ini [1].

Dengan adanya ketersediaan ES membantu problem solving dibidang medis, karena kemampuan teknologi dapat membantu dalam pengelolaan data, penyimpanan hasil diagnosa maupun informasi hasil. Basic knowledge dari pakar diperlukan untuk membangun inference machine dalam sistem, sehingga akan memberikan hasil 
diagnosa seperti pemikiran pakar.

Metode inferensi dalam penelitiannya ini menggunakan Forward Chaining sedangkan reasioning menggunakan Dempster Shafer. Metode Foward Chaining cocok untuk diagnosa awal pada penyakit dengan pelacakan dari gejala-gejala yang diderita. Metode Dempster Shafer merupakan salah satu metode ketidakpastian. Perhitungan ketidakpastian diperlukan dalam sistem, agar diagnosa dapat memberikan keyakinan seperti layaknya Si Pakar. Peranan sistem tidak sepenuhnya menggantikan Si Pakar, namun merupakan sistem yang dapat membantu untuk melakukan pekerjaan seperti halnya pemikiran Si Pakar, dalam bidang yang tak terbatas waktu dan area konsultasi.

Kategori jenis penyakit yang akan dibahas disini adalah Sinusitis, Bronkitis, Polip, Mimisan, Adenoid, Amandel, Otitis Media Akut (OMA).

Dalam penelitiannya para pengembang sistem telah banyak menerapkan beberapa metode untuk memberikan dukungan keputusan diagnosa penyakit pada makhluk hidup. Penelitian-penelitian yang terkait telah menggunakan metode dan konsep dalam sistem dalam menentukan hasil diagnosa sebagai berikut :

Nusai, et.al. mengembangkan sebuah sistem diagnosa penyakit pada babi berbasis web yang dikembangkan untuk petani babi dengan disertai solusi penanganan. Sistem menggunakan 3 tahap penyelesaian yaitu disease screening, disease diagnosis using the symptoms, dan disease diagnosis using swine necropsy lesion. Desease screening untuk merepresentasi usia dan jenis kelamin babi, disease diagnosis using the symptoms merepresentasi pengetahuan ketidak pastian (certainly factor) dengan inferensi determinasi pembobotan gejala berdasarkan data pakar. Disease diagnosis using swine necropsy lesion menggunakan representasi menarik kesimpulan penyakit berdasarkan penelusuran aturan. Hasil dari sistem menunjukkan perbandingan dengan si pakar akurasi desease screening sebesar $97,50 \%$, disease diagnosis using the symptoms sebesar $92,48 \%$ dan didiagnosis dengan lesi sebesar 95,62\% lebih besar dari akurasi sebelumnya [2].

Wahyuni dan Prijodiprojo mengenai pembuatan prototype sistem pakar untuk mendeteksi tingkat resiko penyakit jantung koroner dengan metode Dempster Shafer studi kasus di RS. PKU Muhammadiyah Yogyakarta. Rule yang dibangun ada 30. Data-data yang digunakan sebagai input adalah nilai kolesterol, gula darah, tekanan darah, berat badan, umur yang merupakan 6 faktor resiko, dan gejala tambahan pada pasien. Hasil yang dicapai dengan mesin inferensi Dempster-Shafer dapat dipergunakan untuk mendiagnosa tingkat resiko penyakit Jantung Koroner dengan masukkan berupa gejala serta faktor resiko yang dimiliki pasien. Beberapa kasus yang diujicobakan diperoleh hasil diagnosa yang sama antara perhitungan sistem. Prediksi $100 \%$ dari hasil ujicoba 10 kasus yang didapatkan dari data Rekamedis RS.PKU Muhhammadiyah Yogyakarta [3].

Puspitasari, dkk mengenai sistem pakar untuk mengidentifikasi penyakit mata pada manusia dengan metode Dempster Shafer. Penyakit yang diidentifikasi ada 5 jenis yaitu: Blefaritis, Konjungtivitis, Selulitis Orbitalis, Skleritis, dan Ulkus Kornea. Faktanya ada 16 jenis gejala. Hasil yang dicapai adalah metode Dempster Shafer dapat diterapkan untuk mendiagnosa gejala penyakit pada mata. Hasil perhitungan manual dari data pakar dengan sistem dengan Metode Dempster Shafer adalah sama. [4].

Verina menerapkan metode Forward Chaining sebagai inferensi untuk mendeteksi penyakit THT pada manusia. Dalam pendekatan ini dimulai dari informasi masukkan dan selanjutnya menggambarkan kesimpulan, pelacakan kedepan mencari fakta yang sesuai dengan aturan IF-THEN. Berdasarkan pengujian sistem tingkat keakurasian metode forward chaining untuk mendeteksi penyakit THT yaitu 100\%, dimana sesuai dengan data yang didapat dari pakar THT untuk menentukan penyakit berdasarkan gejala. Dengan data sejumlah 28 penyakit dan 57 gejala [5].

Penelitian yang dilakukan oleh penulis adalah membuat suatu sistem pendukung diagnosa terhadap gejala penyakit pada anak balita, dengan mengambil data dari Puskesmas-Posyandu Kuala Kurun Kalimantan Tengah., Dengan jumlah gejala 26, penyakit 6, solusi 6,dan aturan 6. Metode inferensi menggunakan forward chaining, dan reasioning dengan Dempster Shafer.

\section{METODE}

\section{A. Penyakit Balita}

Menurut Sutanto dalam Hendriana telinga, hidung dan tenggorokan (THT) berhubungan erat lokasinya dengan saluran yang dinamakan saluran "Eustachian tube", sehingga infeksi pada hidung dapat menyebar ke tenggorokan dan sebaliknya. Kelainan pada organ-organ tersebut didiagnosis dan diobati oleh dokter spesialis THT [6].

Infeksi pada saluran napas merupakan penyakit yang umum terjadi pada masyarakat. Secara umum penyebab dari infeksi saluran napas adalah berbagai mikroorganisme, namun yang terbanyak akibat infeksi virus dan bakteri. [7]. Seseorang dapat diketahui mengidap suatu penyakit jika diketahui gejala-gejala yang ditimbulkan 
merupakan proses diagnosa, sehingga Pakar dibidangnya dapat menarik sebuah hipotesa dari gejala yang disampaikan. Hasil hipotesa berupa simpulan identifikasi dari fakta-fakta yang berkaitan memberikan solusi penanganan terhadap suatu penyakit.

Balita merupakan anak berusia dibawah lima tahun, merupakan salah satu periode usia manusia setelah bayi, dengan rentang usia dimulai dari dua sampai lima tahun (24 sampai 60 bulan).

Sinusitis adalah penyakit yang disebabkan oleh virus dan bakteri yang mengakibatkan terjadinya infeksi (inflamasi/peradangan) pada dinding rongga/sinus sekitar hidung [7].

Menurut Everard dan Stark dalam buku saku Bina Farmasi Komunitas dan Klinik, Bronkhitis adalah kondisi peradangan pada daerah trakheobronkhial. Bronkhitis akut umumnya terjadi pada musim dingin, hujan, kehadiran polutan yang mengiritasi seperti polusi udara, dan rokok [7]. Batuk mungkin akan bertahan selama beberapa minggu setelah gejala lainnya menghilang. Batuk yang berkelanjutan bisa membuat dada dan otot perut terasa sakit [8].

Menurut Nuty dalam bahan ajarnya, penyakit Polip akan tampak sebagai benjolan lunak berwarna putih atau keabu-abuan yang tidak disertai nyeri Polip hidung (polip nasi) ialah kelainan mukosa hidung berupa massa lunak yang bertangkai, berbentuk bulat atau lonjong, berwarna putih ke abu-abuan, dengan permukaan licin dan agak bening karena mengandung banyak cairan [9]. Selain itu polip disertai tanda suara serak dan hidung tersumbat Pengobatan polip hidung bisa dilakukan dengan penggunaan obat-obatan. Jika ukuran polip hidung terlalu besar atau polip yang ada tidak bisa disembuhkan dengan obat-obatan, maka akan dilakukan dengan cara operasi [10].

Mimisan adalah pendarahan yang terjadi dari hidung terutama daerah tulang hidung depan terdapat leksus gleselbach, yaitu anyaman pembuluh darah yang dilapisi selaput lendir [11]. Darah dapat keluar dari salah satu atau kedua lubang hidung dengan durasi yang berbeda-beda . Pada anak balita selaput lendir ini masih dalam kondisi tipis sekali. Mimisan dapat disebabkan oleh berbagai hal. Faktor pemicunya dapat berupa penggunaan obat-obatan, keturunan, hingga penyakit.

Adenoid gejalanya mirip amandel, tonsil yang berada dibelakang rongga hidung yang dalam kondisi membesar di usia 3 tahun. Pada anak balita, kondisi ini dapat berkembang menjadi hipertropi adenoid atau adenoid yang membesar sampai menutupi saluran hidung sehingga anak susah bernapas [12].

Radang amandel adalah peradangan yang terjadi pada amandel atau tonsil. Kondisi yang dinamakan juga dengan tonsilitis ini sebagian besar dialami oleh anak-anak. Penyebab radang amandel atau tonsilitis pada umumnya adalah virus dan selebihnya disebabkan oleh bakteri. Umumnya amandel akan membesar pada usia 5 tahun dan merupakan hal yang wajar, biasanya ukuran besarnya sesuai dengan anatomi [13].

Otitis Media Akut (OMA) adalah infeksi yang menyebabkan peradangan pada gendang telinga sehingga tampak merah dan bengkak.. Disfungsi tuba Eustachius berkaitan dengan adanya infeksi saluran napas atas dan alergi. Beberapa anak yang memiliki kecenderungan otitis akan mengalami 3-4 kali episode otitis pertahun atau otitis media yang terus menerus selama $>3$ bulan (Otitis media kronik) [7].

\section{B. Dempster Shafer $(D-S)$}

Dempster Shafer merupakan teori untuk meningkatkan distribusi probabilitas yang dapat memberi kemampuan memodelkan informasi terkait dengan permasalahan ketidakpastian. Secara formal belief structure pada D-S variabel $m$ berada pada himpunan $X$ yang bernilai tidak kosong. $F 1 \ldots . . F q$ disebut elemen fokal, dan $m\left(F_{j}\right) \in$ [0,1] , sehingga $m\left(F_{j}\right)>0$ dan $\sum_{j}^{q} m\left(F_{j}\right)=1$, dimana $m\left(F_{j}\right)$ merupakan sebuah bobot pada $F_{j}$.

Ada variasi interprestasi dari belief structure pada D-S digunakan untuk menghubungkan distribusi probabilitas. Dalam hal ini distribusi probabilitas ada pada ruang himpunan $X$, sehingga $x_{i} \in X$ pada setiap $p_{i}$, dimana $x_{i}$ menunjukkan probabilitas $x_{i}$, dengan ketentuan $\sum_{j} p_{i}=1$. Dalam kerangka D-S nilai $m\left(F_{j}\right)$ diindikasi sebagai sejumlah probabilitas yang dialokasikan dalam $F_{j}$.

Dengan demikian belief structure D-S memberikan informasi yang mengandung dua jenis ketidakpastian, yaitu probabilitas, keacakan dan parameter lain yang berhubungan dengan distribusi probabilitas. Ketidaktepatan dalam informasi sering membutuhkan subjek tambahan informasi untuk melakukan beberapa tugas, terutama yang berkaitan dengan pengambilan keputusan.

Ada 2 langkah penting dapat dikaitkan dengan belief structure m, disebut ukuran kepercayaan oleh Shafer [14].

$$
\begin{aligned}
& P I(A)=\sum_{j, A \cap F_{j} \neq 0} m\left(F_{j}\right) \quad \text { (Plausibility) } \\
& \operatorname{Bel}(A)=\sum_{j, F_{j} \subseteq A} m\left(F_{j}\right) \quad \text { (Belief) }
\end{aligned}
$$


Dengan ketentuan $P(I) \geq \operatorname{Bel}(A)$, dengan $P l(X)=\operatorname{Bel}(X)=1$ dan $P l(\emptyset)=B E L(\emptyset)$. Jika $A C B$ dimana $P(I) \leq P I(B)$ dan $\operatorname{Bel}(A) \leq \underline{\operatorname{Bel}(B)}$. sehingga dapat diindikasikan $\operatorname{Bel}(A) \leq \operatorname{Prob}(A) \leq P I(A)$

Terlihat bahwa kedekatan belief structure menyediakan informasi tentang probabilitas suatu himpunan dengan interval yang tidak tentu. Alternatif dari situasi ini terlihat nilai $P(A)$ berada pada interval $[\operatorname{Bel}(A), P l(A)]$. [14]

Definisi berikut menggambarkan elemen dasar teori D-S [15]:

1) . $m: 2^{\Omega} \rightarrow[0,1]$, dimana $\Omega$ disebut probabilitas dasar jika

$\mathrm{m}(\emptyset)=0 \operatorname{dan} \sum_{A \in 2^{h}} \mathrm{~m}(\mathrm{~A})=1$

2) . Misalnya $\Omega$ adalah sebuah set, ketika $A \subseteq \Omega$ adalah elemen fokus jika $m(A)>0$, selain itu $F(\Omega) C 2^{\Omega}$ mewakili himpunan elemen fokus yang diinduksi oleh $\mathrm{m}$.

3) . Misalnya m adalah probabilitas dasar merupakan fungsi dari suatu set $\Omega$, Belief dari $A \subseteq \Omega$, yang diinduksi oleh $\mathrm{m}$, dapat didefisinikan sebagai berikut :

$\operatorname{Bel}(A)=\sum_{B \subseteq A} m(B)$

4) . Misalnya $\mathrm{m}$ adalah probabilitas dasar merupakan fungsi dari suatu set $\Omega$, Plausibility dari $A \subseteq \Omega$, yang diinduksi oleh $\mathrm{m}$, dapat didefisinikan sebagai berikut :

$P I(A)=\sum_{B \cap A \neq 0} m(B)$

Ketidakpastian pada subset tertentu A didefinisikan oleh interval Belief [ $\operatorname{Bel}(A), P l(A)]$. Perhatikan bahwa perbedaan kecil antara Belief dan Plausibility menunjukkan kepastian tentang keyakinan, sementara perbedaan besar menunjukkan bahwa tidak yakin dengan kepercayaan yang ada.

$P l(A)=1-\operatorname{Bel}(\bar{A})$, dimana $\bar{A}$ adalah komplemen $\operatorname{ke} \Omega$

Ketika probabilitas dasar dihasilkan oleh sumber independen yang berbeda, mungkin timbul kebutuhan untuk menggabungkannya dengan menggabungkan aturan kombinasi D-S sebagai operator fusi.

5) . Misalkan $m 1$ dan $m 2$ merupakan probabilitas dasar, probabilitas gabungan bersama dihitung:

$$
\begin{aligned}
& m_{1,2}(\mathrm{~A})=\frac{1}{1-\mathrm{Z}} \sum_{\mathrm{B} \cap \mathrm{C}=\mathrm{A}} \mathrm{m}_{1}(\mathrm{~B}) \cdot \mathrm{m}_{2}(\mathrm{C}) \\
& \quad \operatorname{dimana} \\
& Z=\sum_{\text {BnC }=\theta} \mathrm{m}_{1}(\mathrm{~B}) \cdot \mathrm{m}_{2}(\mathrm{C})
\end{aligned}
$$

adalah ukuran dari jumlah konflik antara dua probabilitas, sehingga dapat diasumsikan $m 1,2(\varnothing)=0$.

Sehingga sumber berkorelasi tinggi akan dinetralkan dengan rata-rata. Aturan kombinasi dipilih bergantung pada asumsi dan data yang dikumpulkan.

\section{Tahapan proses pembuatan sistem}

Sistem pakar adalah memindahkan kemampuan pakar kedalam komputer. Kemudian digunakan oleh orang yang bukan pakar untuk membantu dalam menyelesaikan masalah. Langkah-langkah yang dilakukan dalam penelitian ini adalah sebagai berikut :

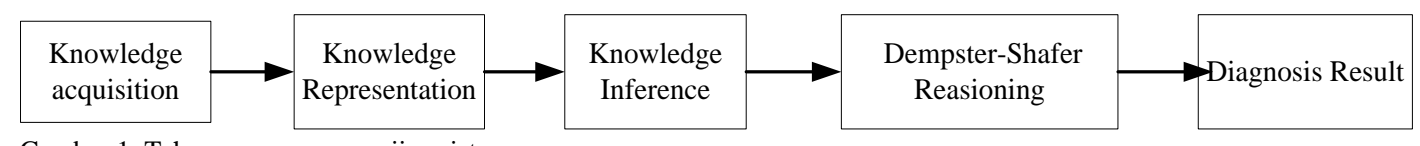

Gambar.1. Tahapan proses penyajian sistem

Gambar 1 menggambarkan proses tahapan pada sistem, dengan penjelasan sebagai berikut :

1. Knowledge acquisition, tahapan untuk memperoleh pengetahuan dari pakar mengenai data-data yang berkaitan dengan informasi gejala-gejala yang menimbulkan penyakit, dan solusi penanganan THT pada balita dari ketujuh penyakit.

2. Knowledge representation, tahapan untuk menentukan aturan (rule). Aturan merupakan prosedur yang diberlakukan pada sistem dalam pengambilan keputusan dalam menyelesaikan masalah (rule-based systems) berdasarkan knowledge acquisition.

3. Knowledge inference, merupakan tahapan penentuan prosedur (program) yang mempunyai kemampuan dalam melakukan penalaran sesuai dengan knowledge acquisition dengan menerapkan knowledge representation pada sistem. Inferensi ditampilkan pada suatu komponen yang disebut inference machine.yang berisikan rules. 
Penelusuran dengan menggunakan runut maju (Forward Chaining), dan hasil konklusi penalaran menggunakan Dempster Shafer.

4. Dempster-Shafer Reasioning, tahapan untuk menentukan hasil konklusi pada sistem menggunakan metode penalaran Dempster Shafer

5. Diagnosis Result, merupakan tahapan untuk memberikan informasi hasil diagnosa pada sistem berupa informasi hasil konklusi penyakit dan solusi penanganan

\section{Alur kerja Sistem}

Dari tahapan-tahapan proses sebelumnya, memudahkan dalam membuat gambaran antar muka yang akan dikembangkan di dalam sistem, hingga menghasilkan informasi terakhir. Gambar 2 merupakan alur proses di dalam sistem.

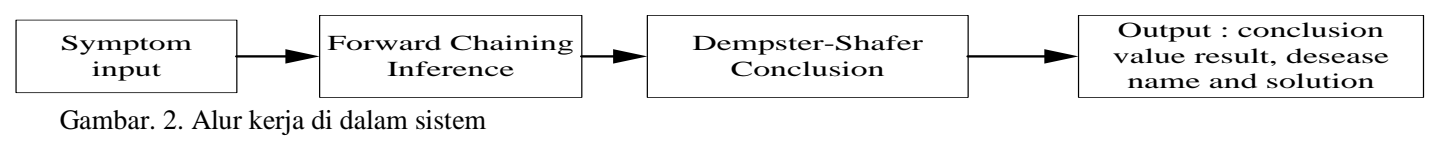

Masukan dari sistem adalah berupa gejala-gejala dari penyakit THT yang dilakukan pada proses symptom input, selanjutnya sistem akan menerapkan inferensi penelusuran dengan menggunakan penelusuran rule dengan Forward Chaining, yang direpesentasikan dalam sebuah kumpulan aturan berbentuk IF-THEN, yang menentukan himpunan aturan kondisi-aksi. Sistem berbasis aturan adalah model yang sederhana dan bisa jadi disesuaikan dan diterapkan pada berbagai masalah yang berbeda [16]. Setiap aturan pada metode inferensi runtut maju hanya diseksekusi satu kali proses pencocokan aturan berhenti bila tidak ada lagi aturan yang bisa dieksekusi.

Hasil penelusuran rule dari tiap-tiap gejala akan ditarik kesimpulan dengan menggunakan penalaran DempsterShafer. Hasil keluaran dari sistem adalah nilai konklusi, nama penyakit dan solusi penanganan.

\section{E. Alir proses Dempster Shafer $(D-S)$}

Alir proses reasioning dengan menggunakan metode D-S yang diproses di dalam sistem dengan menggunakan persamaan (1) hingga (6) dapat dilihat pada Gambar 3.

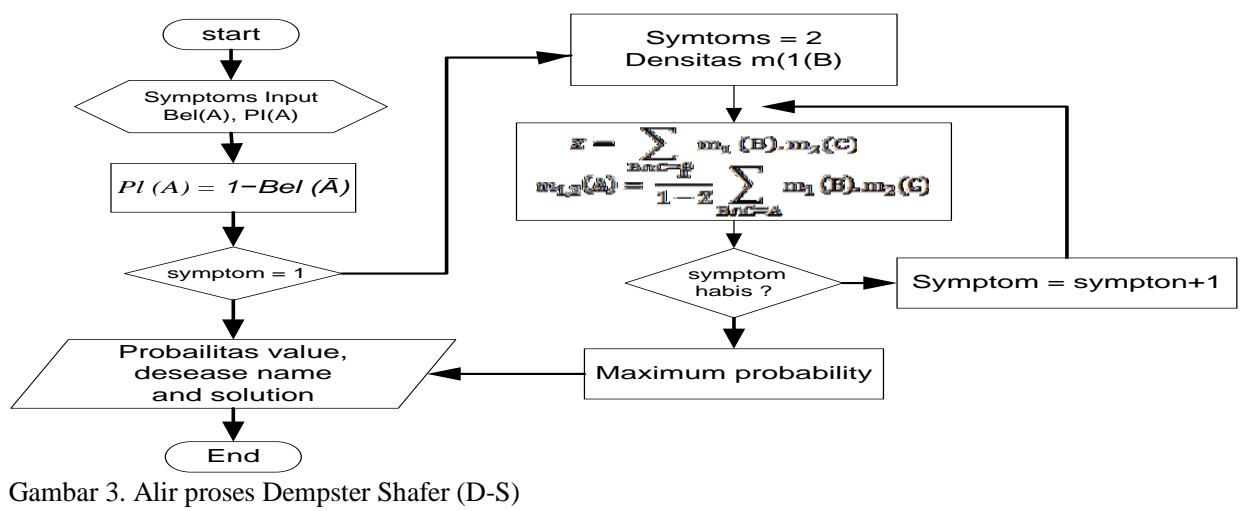

\section{HASIL}

Kebutuhan data yang diperlukan dalam pembuatan aplikasi sistem pakar ini adalah terdiri dari : data gejala, data penyakit, data solusi pencegahan dan penanganan, dan data aturan. Informasi yang dihasilkan oleh sistem adalah identifikasi penyakit hasil kosnklusi diagnosa gejala beserta nama penyakit dan solusi. Data penelitian kasusnya diambil dari Puskesmas Purukcahu di wilayah Kalimantan Tengah. Sistem menyediakan beberapa interface yang akan digunakan dan dikelola oleh pengelola sistem/ pakar dan pasien/ pengguna sistem.

Untuk daftar penyakit yang akan didiagnosa seputar penyakit THT ada 6 jenis yaitu: Sinusitis, Bronkitis, Polip, Mimisan, Amandel, Adenoid, dan Otitis Media Akut. Solusi merupakan saran atau anjuran dari penanganan hasil hipotesa/ kesimpulan dari hasil diagnosa terhadap penyakit yang telah teridentifikasi jenisnya. Solusi akan diberikan pada setiap jenis penyakit .Untuk daftar kode penyakit dan solusi dapat ditunjukkan pada Tabel 1. Aturan pengetahuan untuk mengidentifikasi penyakit THT pada balita didasarkan pada pengetahuan pakar yang didasarkan pada fakta-fakta muncul sehingga dapat memberikan hasil hipotesa. Hasil hipotesa adalah informasi suatu penyakit yang diderita oleh balita. Tabel 2 merupakan aturan/ rule yang dibangun berdasarkan pada gejala-gejala yang mempengaruhi. 
Diagnosa suatu penarikan runutan dari fakta-fakta yang dikaitkan untuk menyimpulkan hasil hipotesa dengan memaparkan komunikasi dari gejala-gejala yang diderita oleh pasien. Untuk daftar gejala dari penyakit yang berkaitan dapat ditunjukkan pada Tabel 3. Tabel 4 menunjukkan basic knowledge munculnya penyakit akibat gejala-gejala yang mempengaruhi dan solusinya.

TABEL 1

PENYAKIT THT PADA BALITA

\begin{tabular}{lcc}
\hline \hline \multicolumn{1}{c}{ Penyakit } & Kode Penyakit & Solusi \\
\hline Sinusitis & P01 & S01 \\
Bronkitis & P02 & S02 \\
Polip & P03 & S03 \\
Mimisan & P04 & S04 \\
Amandel & P05 & S05 \\
Adenoid & P06 & S06 \\
Otitis Media Akut & P07 & S07 \\
\hline \hline
\end{tabular}

TABEL 3

GEJALA PENYAKIT THT PADA BALITA

\begin{tabular}{lc}
\hline \multicolumn{1}{c}{ Gejala } & Kode Gejala \\
\hline Flu berkepanjangan & $\mathrm{G} 01$ \\
Sumbatan dihidung & $\mathrm{G} 02$ \\
Pusing & $\mathrm{G} 03$ \\
Demam & $\mathrm{G} 04$ \\
Mulut berbau & $\mathrm{G} 05$ \\
Batuk kering & $\mathrm{G} 06$ \\
Batuk berdahak & $\mathrm{G} 07$ \\
Sesak nafas & $\mathrm{G} 08$ \\
Benjolan lunak berwarna putih/ abu-abu di & $\mathrm{G} 09$ \\
dalam rongga hidung & \\
Suara serak, hidung tersumbat & $\mathrm{G} 10$ \\
Hipersensitif & $\mathrm{G} 11$ \\
Sering mengupil & $\mathrm{G} 12$ \\
Sakit pilek terus menerus & $\mathrm{G} 13$ \\
Kemasukan benda asing & $\mathrm{G} 14$ \\
Iritasi & $\mathrm{G} 15$ \\
Susah menelan & $\mathrm{G} 16$ \\
Susah bernafas & $\mathrm{G} 17$ \\
Makan sering muntah & $\mathrm{G} 18$ \\
Demam bila capek sedikit saja & $\mathrm{G} 19$ \\
Sering sakit & $\mathrm{G} 20$ \\
Mulut selalu terbuka & $\mathrm{G} 21$ \\
Langit-langit mulut tumbuh cekung keatas & $\mathrm{G} 22$ \\
Gigi rahang atas maju kedepan & $\mathrm{G} 23$ \\
Nyeri ditelinga & $\mathrm{G} 24$ \\
Panas tinggi & $\mathrm{G} 25$ \\
Keluar nanah & $\mathrm{G} 26$ \\
\hline \hline
\end{tabular}

TABEL 2

ATURAN/ RULE PENYAKIT THT PADA BALITA

\begin{tabular}{lc}
\hline \hline \multicolumn{1}{c}{ Aturan } & $\begin{array}{c}\text { Kode } \\
\text { Aturan }\end{array}$ \\
\hline IF G01 AND G02 AND G03 AND G04 AND G05 THEN P01 & R1 \\
IF G06 AND G07 AND G08 THEN P02 & R2 \\
IF G09 AND G10 AND G11 THEN P03 & R3 \\
IF G12 AND G13 AND G14 AND G15 THEN P04 & R4 \\
IF G16 AND G17 AND G18 AND G19 AND G20 THEN P05 & R5 \\
IF G21 AND G22 AND G23 THEN P06 & R6 \\
IF G24 AND G24 AND G25 AND G26 THEN P07 & R7 \\
\hline \hline
\end{tabular}

TABEL 4

DAFTAR BASIC PENGETAHUAN PENYAKIT THT PADA BALITA

\begin{tabular}{|c|c|c|c|c|c|c|c|}
\hline \multirow{2}{*}{ Gejala } & \multicolumn{7}{|c|}{ Penyakit } \\
\hline & P01 & $\mathrm{P} 02$ & P03 & P04 & P05 & P06 & $\mathrm{P} 07$ \\
\hline G01 & $\sqrt{ }$ & & & & & & \\
\hline G02 & $\sqrt{ }$ & & & & & & \\
\hline G03 & $\sqrt{ }$ & & & & & & \\
\hline G04 & $\sqrt{ }$ & & & & & & \\
\hline G05 & $\sqrt{ }$ & & & & & & \\
\hline G06 & & $\sqrt{ }$ & & & & & \\
\hline G07 & & $\sqrt{ }$ & & & & & \\
\hline G08 & & $\sqrt{ }$ & & & & & \\
\hline G09 & & & $\sqrt{ }$ & & & & \\
\hline G10 & & & $\sqrt{ }$ & & & & \\
\hline G11 & & & $\sqrt{ }$ & & & & \\
\hline G12 & & & & $\sqrt{ }$ & & & \\
\hline G13 & & & & $\sqrt{ }$ & & & \\
\hline G14 & & & & $\sqrt{ }$ & & & \\
\hline G15 & & & & $\sqrt{ }$ & & & \\
\hline G16 & & & & & $\sqrt{ }$ & & \\
\hline G17 & & & & & $\sqrt{ }$ & & \\
\hline G18 & & & & & $\sqrt{ }$ & & \\
\hline G19 & & & & & $\sqrt{ }$ & & \\
\hline G20 & & & & & $\sqrt{ }$ & & \\
\hline G21 & & & & & & $\sqrt{ }$ & \\
\hline G22 & & & & & & $\sqrt{ }$ & \\
\hline G23 & & & & & & $\sqrt{ }$ & \\
\hline G24 & & & & & & & $\sqrt{ }$ \\
\hline G25 & & & & & & & $\sqrt{ }$ \\
\hline G26 & & & & & & & $\sqrt{ }$ \\
\hline Solusi & S01 & S02 & S03 & S04 & S05 & S06 & S07 \\
\hline
\end{tabular}

\section{A. Implementasi Pengelola Sistem}

Gambar 4 merupakan tampilan awal saat menjalankan sistem. Pihak user diharapkan untuk memilih salah satu akses yang digunakan, sebagai pengelola sistem ataupun pengguna sistem. Halaman pengelola sistem pada Gambar 5 terdiri dari enam menu yaitu "GEJALA", "PENYAKIT", "SOLUSI", "ATURAN", "DIAGNOSA", "INFORMASI".

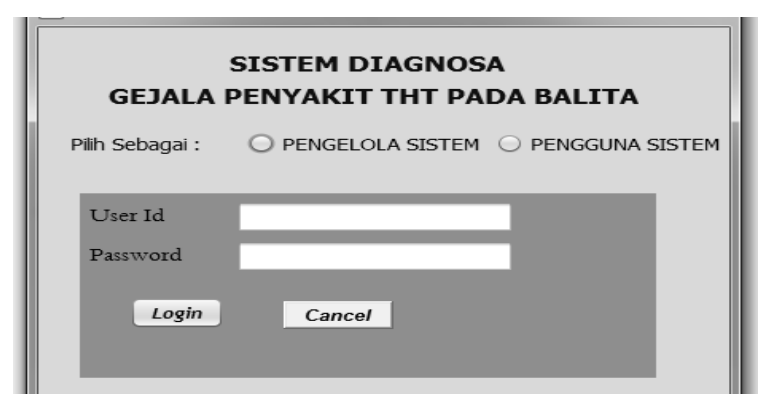

Gambar 4. Menu utama pengelola sistem

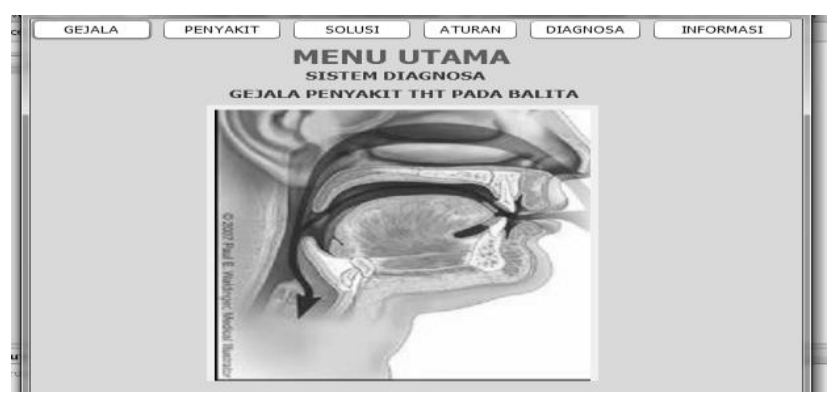

Gambar 5. Menu utama pengelola sistem

Pengelolaan "Gejala" pada interface Gambar 6 merupakan halaman kelola gejala . Gambar 7 merupakan halaman pengelolaan "Penyakit", masukan dari user adalah kode penyakit, nama penyakit dan nilai probabilitas. 
Pengelolaan "Solusi" menampilkan halaman pengelolaan solusi oleh user seperti yang ditunjukkan interface Gambar 8.

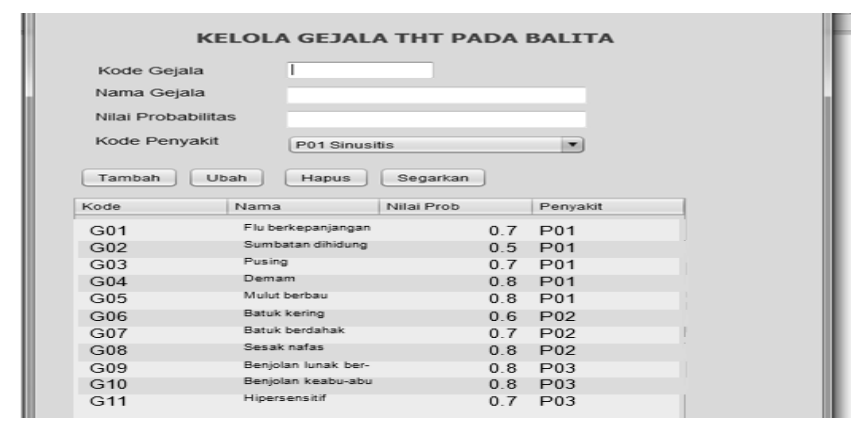

Gambar 6. Interface pengelolaan gejala

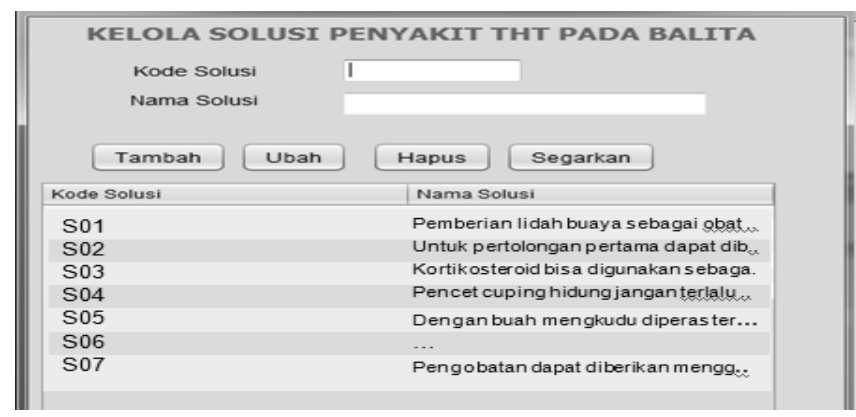

Gambar 8. Interface pengelolaan solusi

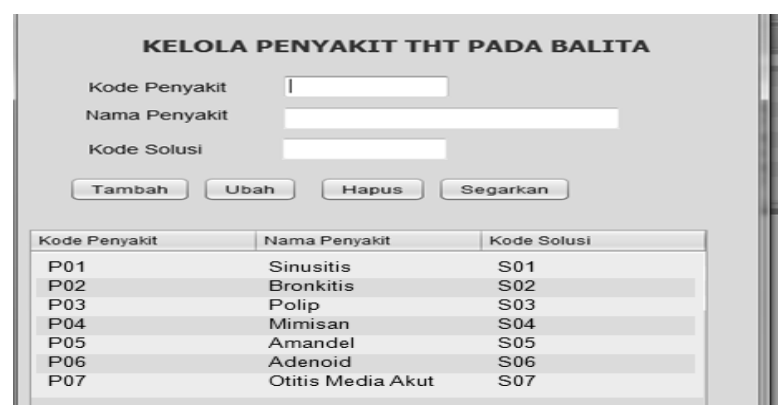

Gambar 7. Interface pengelolaan penyakit

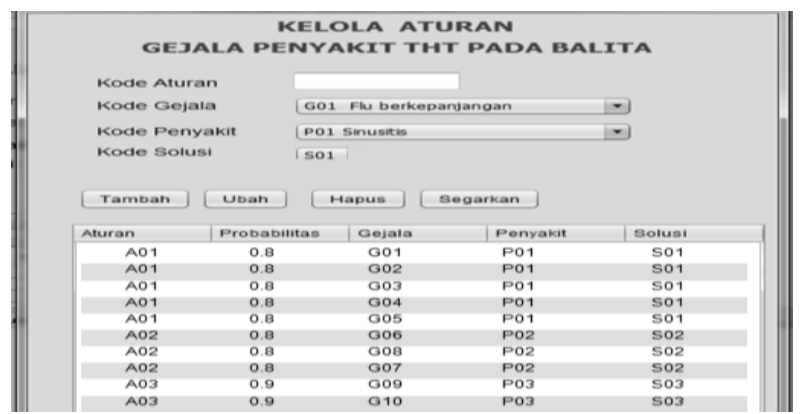

Gambar 9. Interface pengelolaan aturan

Pengelolaan "aturan" pada interface Gambar 9 akan menampilkan halaman pengelolaan aturan oleh user, dengan mengisikan kode aturan, kode gejala, kode penyakit.

\section{B. Implementasi interface pengguna sistem}

Gambar 10 merupakan tampilan halaman pengguna sistem, dengan tiga deretan menu yaitu "DIAGNOSA", "INFORMASI", "KEMENU”.

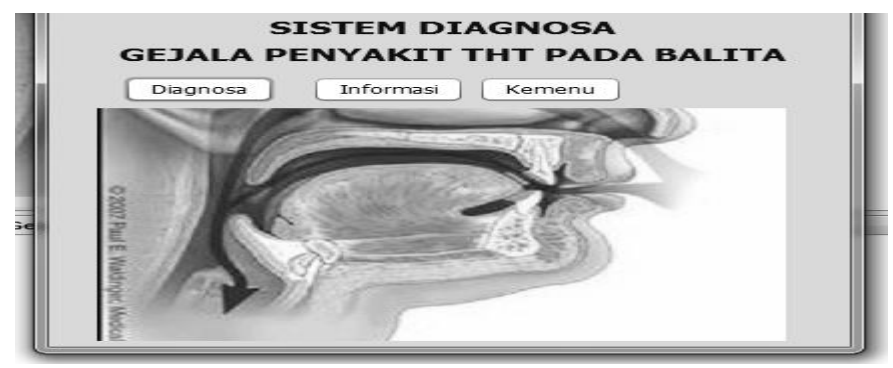

Gambar 10. Interface menu utama pengguna sistem

Gambar 11 merupakan halaman dialog pengguna untuk melakukan diagnosa, dengan menentukan pilihan gejala-gejala sehingga menampilkan hasil diagnosa penyakit, dan solusi penanganan. Gambar 12 merupakan tampilan halaman informasi mengenai seputar penyakit THT pada balita.

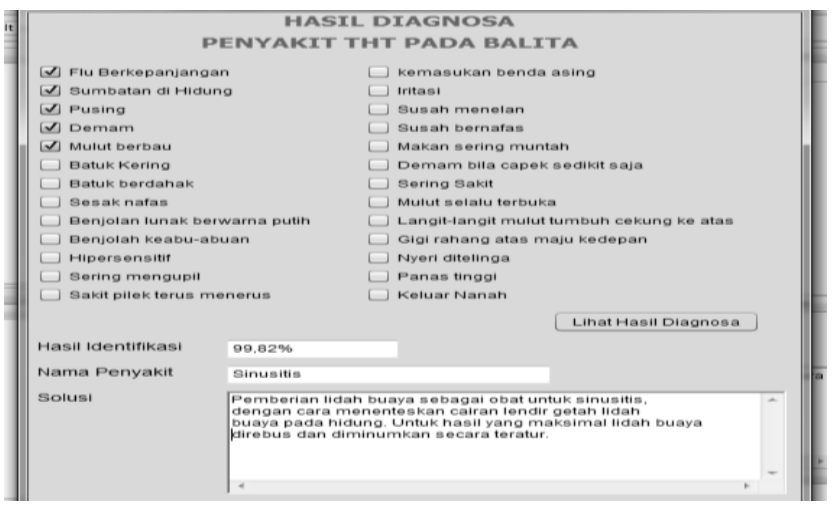

Gambar 11. Interface halaman diagnosa

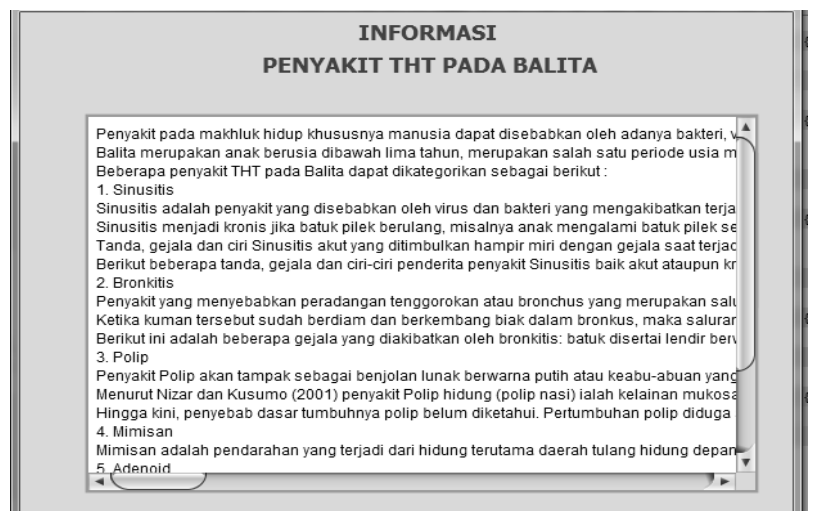

Gambar 12. Interface halaman informasi pengguna sistem 


\section{PEMBAHASAN}

Kasus dengan 1 penyakit akan diperhitungkan secara manual dengan metode Dempster Shafer terhadap gejala penyakit THT pada balita. Diketahui pasien memiliki gejala-gejala sebagai berikut : Menderita flu pada jangka waktu cukup lama, Bagian hidung mengalami penyumbatan, sering pusing kepala, kondisi badan demam, mulut berbau.

Dari faktor gajala-gejala yang ditimbulkan oleh pasien tersebut, bahwa pasien mengalami gejala G01, G02, G03, G04, dan G05, hasil penelusuran hitungan secara manual adalah sebagai berikut:

a. Gejala 1 adalah Flu berkepanjangan, langkah pertama berpengaruh pada Gejala 1 dengan menghitung nilai belief (bel) dan plausability $(\theta)$ dengan formula (4) :

Gejala 1 : Flu berkepanjangan (G01).

Maka : M1 G01 (bel) $\}=0,7$

$\mathrm{M} 1\{\mathrm{G} 01(\Theta)\} \quad=1-0,7=0,3$

b. Gejala 2 adalah Sumbatan di hidung, langkah kedua berpengaruh pada Gejala 2 dengan menghitung nilai bel dan $\theta$ dengan formula (4) :

Gejala 2 : Sumbatan di hidung (G02).

Maka $\quad$ : $\mathrm{M} 2\{\mathrm{G} 02($ bel $)\}=0,5$

$\mathrm{M} 2\{\mathrm{G} 02(\Theta) \quad\}=1-0,5=0,5$

Gejala yang ditimbulkan G01 dan G02 mengarah pada penyakit Sinusitis (P01). Ilustrasi nilai keyakinan dua gejala pada G01 dengan G02, seperti terlihat pada Tabel 5.

TABEL 5

ILUSTRASI NILAI KEYAKINAN TERHADAP DUA GEJALA

\begin{tabular}{|c|c|c|}
\hline Gejala 1 dan 2 & $\mathrm{M} 2\{\mathrm{P} 01\} \quad 0,5$ & $\mathrm{M} 2\{\Theta\}$ \\
\hline $\mathrm{M} 1\{\mathrm{P} 01\}=0,7$ & $\{\mathrm{P} 01\}$ & $\begin{cases}\mathrm{P} 01\} & 0,35\end{cases}$ \\
\hline $\operatorname{M1}\{\Theta\}=0,3$ & $\{\mathrm{P} 01\}$ & 0,15 \\
\hline
\end{tabular}

Selanjutnya menghitung tingkat keyakinan $m$ combine dengan formula (6)

$$
\begin{aligned}
& \text { M3 }\left\{\text { P01 }=\frac{(0,7 \times 0,5)+(0,3 \times 0,5)+(0,7 \times 0,5)}{1-0}=\frac{0,35+0,15+0,35}{1}=0,85\right. \\
& \text { M3 }\{\Theta\}=\frac{(0,3 \times 0,5)=\frac{0,15}{1}=0,15}{1-0}
\end{aligned}
$$

c. Gejala 3 adalah pusing, langkah ketiga berpengaruh pada G01, G02 dengan G03 dengan menghitung nilai bel dan $\theta$ dengan formula (4) :

Gejala 3 : p using (G03).

Maka : M4 $\{\mathrm{G} 03($ bel $)\}=0,7$

$\mathrm{M} 4\{\mathrm{G} 03(\Theta)\} \quad=1-0,7=0,3$

Gejala yang ditimbulkan G01, G02 dan G03 mengarah pada penyakit Sinusitis (P01). Ilustrasi nilai keyakinan tiga gejala G01, G02 dengan G03, seperti terlihat pada Tabel 6.

TABEL 6

\begin{tabular}{|c|c|c|c|}
\hline \multicolumn{2}{|c|}{ Gejala 1,2 dan 3} & M4 $\left\{\begin{array}{lll}\mathrm{P} 01\} & 0,7 \\
\end{array}\right.$ & M4 $\{\Theta\}$ \\
\hline $\mathrm{M} 3\{\mathrm{P} 01\}=$ & 0.85 & $\{\mathrm{P} 01\} \quad 0,595$ & $\{\mathrm{P} 01\} \quad 0.255$ \\
\hline $\operatorname{M} 3\{\theta\}=$ & 0.15 & $\{\mathrm{P} 01\}$ & 0.045 \\
\hline
\end{tabular}

ILUSTRASI NILAI KEYAKINAN TERHADAP TIGA GEJALA

Selanjutnya menghitung tingkat keyakinan m combine dengan formula (6) .

M5 $\{\mathrm{P} 01\}=\underline{(0,85 \times 0,7)+(0,15 \times 0,7)+(0,85 \times 0,3)}=\underline{0,595+0,105+0,255}=0,955$

$$
\text { M5 }\{\Theta\}=\frac{(0,15 \times 0,3)}{1-0}=\frac{0,045}{1}=0,045
$$

d. Gejala 4 adalah demam, langkah ketiga berpengaruh pada G01, G02, G03 dengan G04 dengan menghitung nilai belief (bel) dan plausability ( $\Theta)$ dengan formula (4) :

$$
\begin{array}{lll}
\text { Gejala } 4 & : \operatorname{demam}(\mathrm{G} 04) & \\
\text { Maka } & \text { M6 }\{\mathrm{G04}(\mathrm{bel})\} & =0,8 \\
& \text { M6 }\{\mathrm{G} 04(\Theta)\} & =1-0,8=0,2
\end{array}
$$

Berdasarkan penelusuran sebelumnya gejala yang ditimbulkan G01, G02 dan G03 mengarah pada penyakit Sinusitis (P01), demikian dengan G04. Ilustrasi keyakinan empat gejala G01, G02, G03 dengan G04, seperti terlihat pada Tabel 7. 
TABEL 7

ILUSTRASI NILAI KEYAKINAN TERHADAP EMPAT GEJALA

\begin{tabular}{|c|c|c|}
\hline Gejala $1,2,3$ dan 4 & $\mathrm{M} 6\{\mathrm{P} 01\} \quad 0,8$ & $\mathrm{M} 6\{\Theta\}$ \\
\hline M5 $\{\mathrm{P} 01\}=0,955$ & $\{\mathrm{P} 01\} \quad 0,764$ & $\begin{array}{lll}\text { P01 } & 0,191\end{array}$ \\
\hline $\mathrm{M} 5 /\{\Theta\}=0,045$ & $\{\mathrm{P} 01\} \quad 0,036$ & $\{\Theta\} \quad 0,009$ \\
\hline
\end{tabular}

Selanjutnya menghitung tingkat keyakinan m combine dengan formula (6).

$$
\begin{aligned}
& \text { M5 }\{\mathrm{P} 01\}=\frac{(0,955 \times 0,8)+(0,045 \times 0,8)+(0,955 \times 0,2)}{1-0} \\
& =\frac{0,764+0,036+0,191}{1}=0,991 \\
& \text { M5 }\{\Theta\}=\frac{(0,45 \times 0,2)}{1-0}=\frac{0,009}{1}=0,009
\end{aligned}
$$

e. Gejala 5 adalah mulut berbau, langkah ketiga berpengaruh pada G01, G02, G03, G04 dengan G05 dengan menghitung nilai bel dan $\theta$ dengan formula (4):

Gejala 5: mulut berbau (G05)

$$
\begin{aligned}
\text { Maka }: \text { M7 }\{\mathrm{G} 05(\mathrm{bel})\} & =0,8 \\
\mathrm{M} 7\{\mathrm{G} 05(\Theta)\} & =1-0,8=0,2
\end{aligned}
$$

\begin{tabular}{|c|c|c|}
\hline Gejala $1,2,3,4$ dan 5 & M6 $\{\mathrm{P} 01\} \quad 0,8$ & $\operatorname{M6}\{\Theta\}$ \\
\hline M5 $\{\mathrm{P} 01\}=0,991$ & 0,7928 & 0,1982 \\
\hline $\mathrm{M} 5 /\{\Theta\}=0,009$ & 0,0072 & 0,0018 \\
\hline
\end{tabular}

Gejala yang ditimbulkan G01, G02, G03 dan G04 mengarah pada penyakit Sinusitis (P01), seperti halnya G05. Ilustrasi nilai keyakinan lima gejala G01, G02, G03, G04 dengan G05, seperti terlihat pada Tabel 8.

TABEL 8.

ILUSTRASI NILAI KEYAKINAN TERHADAP LIMA GEJALA

Selanjutnya menghitung tingkat keyakinan $\mathrm{m}$ combine dengan formula (6)

$$
\begin{aligned}
& \text { M8 }\{\mathrm{P} 01\}=\underline{(0,991 \times 0,8)+(0,009 \times 0,8)+(0,991 \times 0,2)} \\
& 1-0 \\
& =\underline{0,7928+0,0072+0,1982}=0,9982
\end{aligned}
$$

Prosentase $\mathrm{P} 01=0,9982 \times 100 \%=99,82 \%$

$\operatorname{M} 8\{\Theta\}=\frac{(0,009 \times 0,2)}{1-0}=\frac{0,0018}{1}=0,0018$

Prosentase $\Theta=0,0018 \times 100 \%=0,18 \%$

Dari hasil perhitungan manual dengan penelusuran forward chaining menunjukan bahwa semua gejala mengarah pada penyakit Sinusitis (P01) dengan nilai belief (bel) $99,82 \%$ dan plausability 0,18\%. Hasil dari sistem dapat dilihat pada Gambar 13.

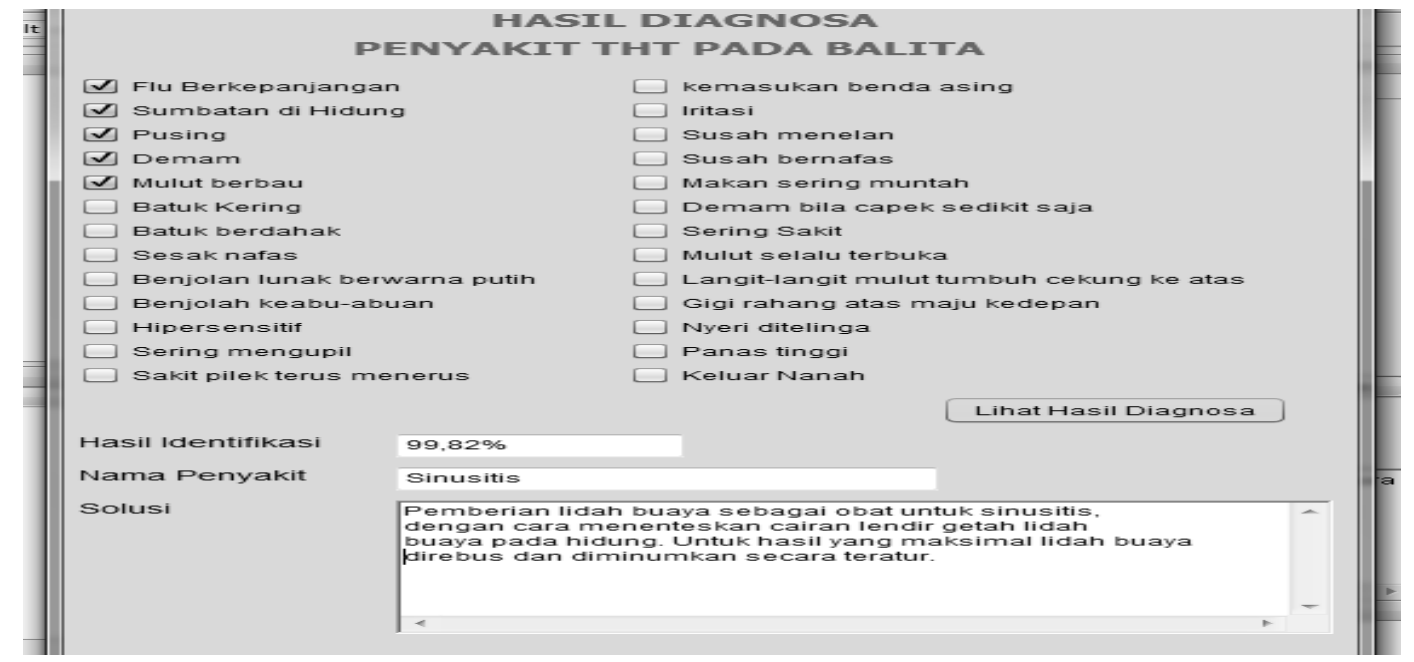

Gambar .13. Hasil diagnosa pada sistem 
Dari perhitungan yang dilakukan secara manual dengan sistem menunjukkan hasil yang sama. Faktor yang berpengaruh adalah penetapan rule yang dibangun di dalam database, sehingga memudahkan hasil penelusuran forward chaining.

Penelusuran forward chaining dan nilai probabilitas pada masing-masing gejala mendukung pada proses perhitungan dengan Dempster Shafer. Pengaruh lain adalah dengan mengatur susunan gejala di database sehingga memudahkan penelusuran. Sistem dapat memberikan informasi hasil perhitungan dengan Dempster Shafer dan informasi penyakit hasil diagnosa serta solusinya.

\section{SIMPULAN DAN SARAN}

\section{A. Simpulan}

Dari hasil penelitian mengenai sistem diagnosa penyakit THT pada balita dapat disimpulkan sebagai berikut :

1. Sistem dapat melakukan update terhadap pengelolaan data seperti data penyakit, gejala, solusi penanganan, serta aturan penyakit. Hal ini membantu user bila ada perubahan knowledge acquisition dapat disesuaikan dengan data pada sistem .

2. Teori Dempster Shafer dapat diterapkan didalam sistem sehingga menghasilkan konklusi hasil diagnosa penelusuran gejala dengan informasi nilai probabilitas penyakit yang sesuai dengan perhitungan manual.

3. Sistem menerapkan pengelolaan aturan di database untuk mendukung update pada knowledge inference yang dipengaruhi oleh perubahan knowledge representation sehingga hasil akhir akan menyesuaikan perubahan aturan.

\section{B. Saran}

Saran yang dapat diambil dari penelitian ini adalah sebagai berikut :

1. Dikembangkan melalui pemrograman lain berbasis android atau berbasis web.

2. Dikembangkan menggunakan metode lain dari Sistem Pakar, dengan JST atau Fuzzy.

3. Dikembangkan untuk kasus penyakit yang lain, tidak hanya berfokus pada THT pada balita.

\section{REFERENSI}

[1] W.P. Wagner, "Trends in expert system development: A longitudinal content analysis of over thirty years of expert system case studies", Expert Systems With Applications, An International Journal, PII: S0957-4174(17)30038-6 DOI: 10.1016/j.eswa.2017.01.028 Reference: ESWA 11076, doi: 10.1016/j.eswa.2017.01.028. 2017.

[2] C. Nusai, S. Cheechang, S. Chaiphech, and G. Thanimkan, "Swine-Vet : a Web-based Expert System of Swine Disease Diagnosis", The 5th International Conference on Current and Future Trends of Information and Communication Technologies in Healthcare (ICTH), Procedia Computer Science 63 ( 2015 ) 366 - 375. www.sciencedirect.com 2015.

[3] E.G.,Wahyuni, W. Prijodiprojo, "Prototype Sistem Pakar untuk Mendeteksi Tingkat Resiko Penyakit Jantung Koroner dengan Metode Dempster Shafer (Studi Kasus di RS. PKU Muhammadiyah Yogyakarta)", Indonesian Journal of Computing and Cybernetics Systems (IJCCS), Vol. 7 No. 2 July 2013, Pp. 133-134 ISSN : 1978-1520. EISSN: 2460-7258, A publication of IndoCEISS. FMIPA UGM, Yogyakarta, 2013.

[4] T.D. Puspitasari, R. Septiriana, V. Ayu, "Sistem Pakar Identiifkasi Penyakit Mata Menggunakan Metode Dempster Shafer", Prosiding Seminar Nasional Komputer dan Informatika Terapan, ISSN 2477-5649,Teknologi Informasi Politeknik Negeri Jember, Jawa Timur, 2015.

[5] W. Verina, "Penerapan Metode Forward Chaining untuk Mendeteksi Penyakit THT", Jurnal teknik Informatika dan sistem Informasi (JATISI), Vol.1 No. 2 March 2015. ISSN: 24074322, STMIK Global Informatika MDP I IndoCEISS, 2015.

[6] Y. Hendriana, "Program Bantu Identifikasi Penyakit THT", Simposium Nasional Teknologi Terapan (SNTT). ISSN 2339-028X. pp 58 -63, Universitas Ahmad Dahlan, Yogyakarta, 2015.

[7] Bina Kefarmasian dan Alat Kesehatan, "Pharmaceutical Care Untuk Penyakit Infeksi Saluran Pernapasan, Direktorat Bina Farmasi Komunitas dan Klinik”, Departemen Kesehatan RI, 2005.

[8] http://www.alodokter.com/bronkitis, diunduh Maret 2017.

[9] W. Nuty, N.W. Nizar, dan E. Mangunkusumo, "Buku Ajar Ilmu Kesehatan Telinga, Hidung dan Tenggorokan Leher", Edisi ke-5. Dalam Soepardi EA, Iskandar N, Editor. Jakarta : Balai Penerbit FKUI. Hal. 125-7, 2001.

[10] http://www.alodokter.com/polip/pengobatan, diunduh Maret 2017.

[11] http://www.alodokter.com/hati-hati-saat-anak-sering-mimisan, diunduh Maret 2017.

[12] http://www.alodokter.com/Adenoid, diunduh Maret 2017.

[13] http://www.alodokter.com/radang-amandel, diunduh Maret 2017.

[14] R.R. Yager, N. Alajlan, "Dempster-Shafer belief structures for decision making under uncertainty", Knowledge-Based Systems, journal homepage:, http://dx.doi.org/10.1016/j.knosys.2014.12.031, www.elsevier.com/locate/knosys, 2015

[15] L.Troiano, L.J. Rodríguez-Muñiz, I. Díaz, "Discovering user preferences using Dempster-Shafer theory", Fuzzy Sets and Systems, www.sciencedirect.com, http://dx.doi.org/10.1016/j.fss.2015.06.004, 0165-0114/@2015 Published by Elsevier B.V, www.elsevier.com/locate/fss. 2015.

[16] M.d. M. Roldán-García, J. García-Nieto, J. F. Aldana-Montes, "Enhancing semantic consistency in anti-fraud rule-based expert systems", Expert Systems With Applications 90 (2017) 332-343, journal homepage: www.elsevier.com/locate/eswa, http://dx.doi.org/10.1016/j.eswa.2017.08.036 , 2017. 